\section{p.132 生理学的研究}

263. 全出持久性トレーニング手段の生理学的研究（そ の 1)

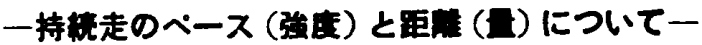
東京数育大学スポーツ研究所

○高松 羔，金原 可 岛取大学 油 可 利

われわれの研究は，全身持久性トレーニング手段とし てインターバルトレーニング法ととるに広く用いられて

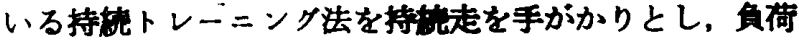
の强度や具の持つ特性を生理学的に究明し，持㛎卜レー ニング法によるトレニング手段を体禾的に明きらかにし ようとするにある.

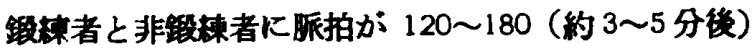
にあがる筑用内の 5 段㳻のペースでトレッドミル走を行 なわせた，派拍数を運動の強さの指標としてとらえ，眽

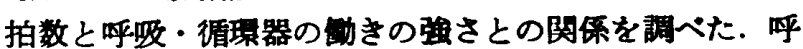

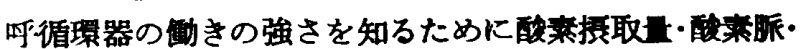

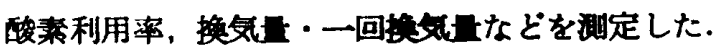

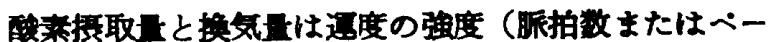
ス）が高くなるほど多くなった。このことは，呼吸・䛻 球器が全体としてより強く的いていることを示するので ある.

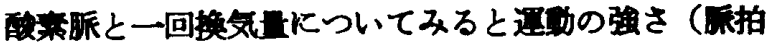
数）が弱い場合と運峌の強い場合との差はきわめて少な
い（図盟）このことは，源拍が120〜150になる程度 の運功の溨合でる，呼吸・倠棵器は一面からとらえると 強く利てており，独自のトレーニンク奶果が得られるこ とを示惨するるのである。

したがって，持请については，一定の脈拍のつつく よ5なぺースによる手段，唋拍は上年するが必要な破恋 を走りながら颃取できるぺースによる手段，走るのに要

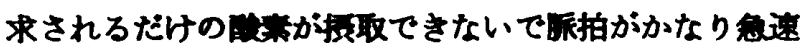

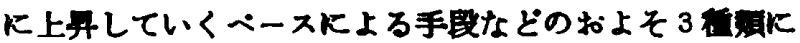
いいて、ペースととるに，つつけて走る望ましい蛙を る含めて，夷柡のトレーニングを通してる柃郡していく.

\section{O. PULSE}

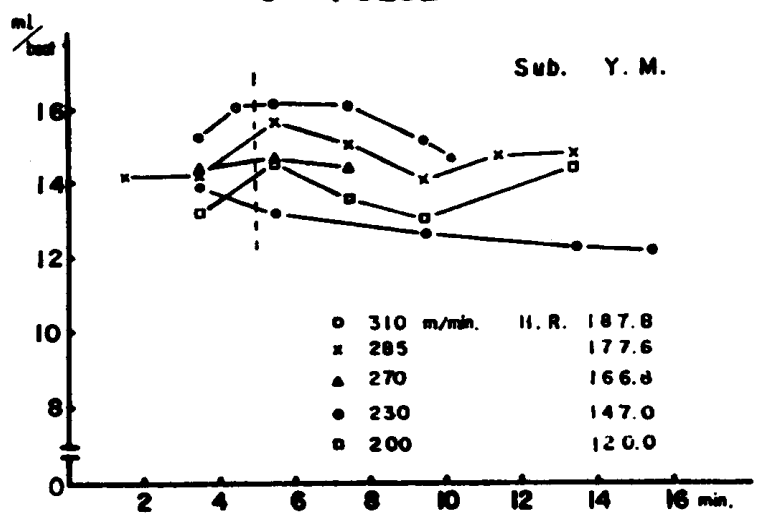

264. 凉死の研范（第44

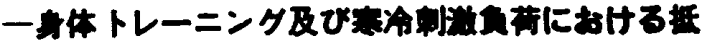
扏性について一

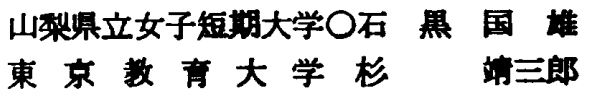

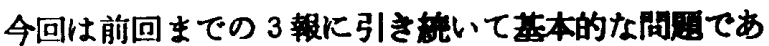
ろ. 四季の変化と篹冷に対する抵抗性について，成育日 数の程過と寒冷に対する抵抗性について明らかにし，更 に身体トレーニング負荷に上る寒冷に対する抵抗性につ いて実験をおこなつたので埌告する。

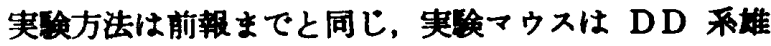
マウスを使用した，実筑期日は昭和 42 年 4 月より昭和 43 年 8 月まで.

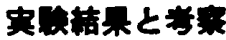

1. 四乎と寒冷に対する抵抗性について.

凍死時間については12，1，2月の冬期が投る延長し，

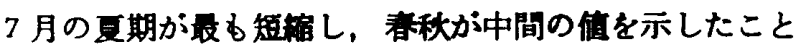
は春夏秋冬の爭節の变化が生体内で一つ週期を作って 適応していることを意朱するるのであろう．副罗重につ いても同粎の結果を得た。

2. 成育日数の释過と寒令に対すする抵抗性について。 （四表㟥照）

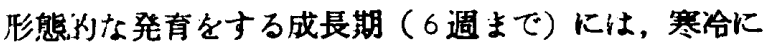

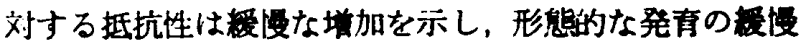

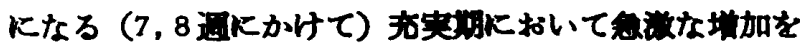

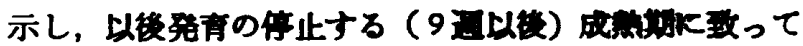
除々に娍少する結果を得た.

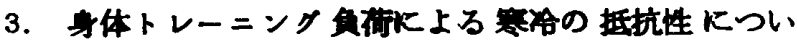
$\tau$.

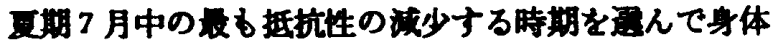

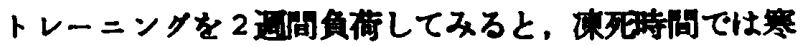

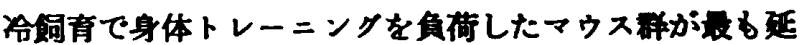

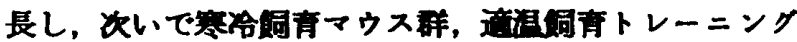

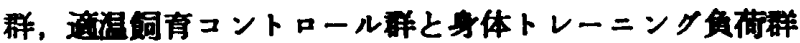

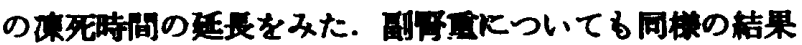
をみた。

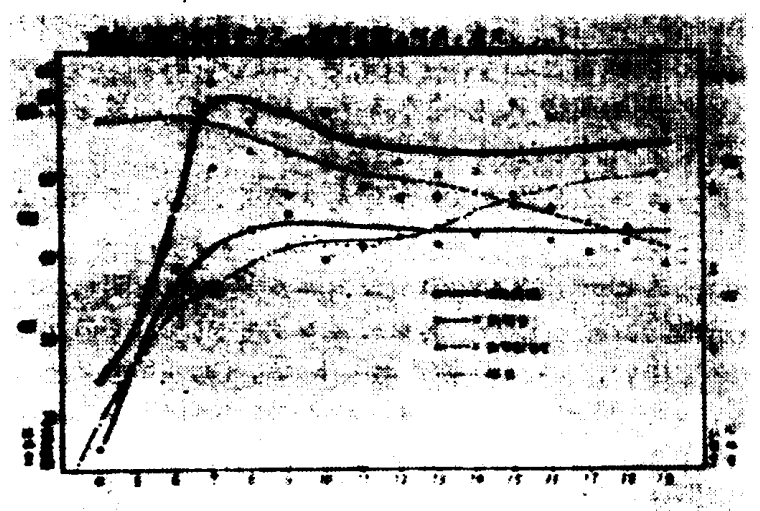

